Shulman's analysis is extremely well formulated, the breadth of the subject matter may still leave the reader very unsure as to the boundaries of the area, and for further reading he may decide that he had better read up all areas of psychology.

In spite of the wide content area, the factor analytic approaches to personality are again conspicuously absent. I find the absence of discussion of the theories of Cattell and Eysenck in both books rather puzzling in view of the pertinence of these approaches to issues involving the nomothetic trait and type concepts of personality, the extensive experimental work that has been conducted in relation to them and the ubiquitous presence of studies using the 16PF and the EPI. I would have thought Eysenck's behaviouristic analysis would have been particularly appropriate to Sherman's discussion of the behaviourism/situationism issue.

Both books assume little previous psychological knowledge of the reader and are easily comprehended. However, I feel that they will be of most value as supplementary, rather than main texts in personality. In this role both are sufficiently individualistic to assume equal prominence.

Graham F. Wagstaff is Lecturer in Personality and Social Psychology at the University of Liverpool, UK.

\section{Surveying microbiology}

\section{D.G. Smith}

Biology of Microorganisms. By T.D. Brock. Third edition. Pp.802. (PrenticeHall International: Englewood Cliffs, New Jersey and Hemel Hempstead, UK, 1979.) Hardback £17.15. The Life of Yeasts. By H.J. Phaff, M.W. Miller and E.M. Mrak. Second edition. Pp.341. (Harvard University Press: Cambridge, Massachusetts and London, 1979.) £10.50.

IN these days of multi-authorship of textbooks, it is becoming increasingly rare for a major textbook to have a single author. T.D. Brock's production of three editions of Biology of Microorganisms within a decade must therefore be acknowledged as a remarkable achievement and it confers the advantage of a uniformity of style throughout the work.

The third edition follows the general format of earlier editions: the pages are large and attractively laid out although often wasteful of space. The subject coverage remains comprehensive and has been extensively updated to cover recent developments in areas such as recombinant DNA and bioenergetics.

A welcome addition to this edition is the incorporation of what the author calls "vignettes" on historical aspects of microbiology. These occur throughout the text labelled "a bit of history". Although these sections can easily be skipped, an appreciation by students of the historical development of a piece of knowledge is certainly to be encouraged.

Another feature of the new edition is the inclusion of five appendices ( 42 pages) containing detailed information on energy calculations, mathematics of growth, biochemical pathways, bacterial classification and microscopy.

This book is one of only two or three available titles which can be recommended as the main textbook purchase by undergraduate students of microbiology.

Now, where would we be without yeasts? For millennia they have been in the service of man making alcoholic beverages and raising bread. They are as domesticated as the cow: no other microorganism is as well known or as widely used.

The second edition of The Life of Yeasts is an authoritative but highly readable account of most aspects of the properties and usefulness of the yeasts. The authors set the scene with a brief historical chapter which also introduces us to the fact that yeasts are a heterogeneous collection of fungi from the Ascomycotina, Basidiomycotina and the Deuteromycotina; the unifying features being absence of asexual spores (conidia) and the ability to live as single cells. Six chapters deal mainly with the cell biology of yeasts and three with their ecology and practical applications. Included in the latter is a description of recent developments in the utilisation of yeast cells as food (single cell protein). Yeasts grown on hydrocarbons or carbohydrates are already being fed to animals and there can be little doubt that this will become increasingly important. Another aspect of mounting significance is the spread of pathogenic yeasts freed from bacterial competition by the extensive use of antibiotics.

This book is suitable for the nonspecialist at school or college but there is also an appendix containing reference material on classification and characteristics of yeast genera which will be useful to the specialist.

D.G. Smith is Senior Lecturer in Microbiology in the Department of Botany and Microbiology, University College London, UK.

\section{Field and Laboratory Exercises in Ecology}

S.D. Wratten and G.L.A. Fry

This book represents the first practical integration of quantitative exercises in plant and animal ecology. Fifty-six exercises, grouped in pairs of complementary field and laboratory experiments and arranged round five major ecological themes, and worked through in full detail and a further 150 variations, some suitable for long term projects, are offered.

Paper $£ 7.50$

\section{New titles in the}

'Studies in Biology' series:

\section{Vocal Communication in Birds}

Clive K. Catchpole

The underlying theme of the book is not only to show how birds communicate with their vocalizations, but also to discover what information is being passed and why. In spite of recent advances, the central problem of why birds have evolved such complex and varied vocalizations remains one of the most interesting, challenging and elusive questions in biology.

Paper $£ 2.40$

\section{Influences on Animal Growth and Development}

\section{Roy A.L. Batt}

This book, the first of its kind, is an introduction, not so much to the processes of growth and development, but to the influences on these processes. It will be of use and interest both to the biologist and to the agriculturist.

Paper $£ 2.20$ approx

Publication March

\section{Collagen:}

\section{The Anatomy of a Protein}

John Woodhead-Galloway

Collagen is one of the best characterized proteins. Dr Woodhead-Galloway shows how from the knowledge of its primary molecular structure, one can logically build models of microfibril and fibril properties that produce an accurate picture of the protein's function in living tissues.

Paper $£ 2.20$ approx

Publication April

\section{Social Behaviour of Animals}

John M. Deag

'Social behaviour' is behaviour involving two or more animals of the same species. This comprehensive and up to date book introduces the reader to the very topical subject of social behaviour and its adaptive significance.

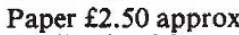

Publication May

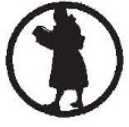

Edward Arnold 41 Bedford Square London WC1B 3DQ 